\title{
DOMESTIC RESOURCE MOBILIZATION, FINANCIAL ACCESS AND INCLUSION FOR INCLUSIVE GROWTH IN NIGERIAN
}

\author{
Nwele, J. Obasi, PhD, mimc ${ }^{1 *}$, Ngene, Amuche $\mathrm{N}^{2}$, Uduimoh, Anthony A, $\mathbf{P h D}^{3}$ \\ *1Department of Business Administration, Renaissance University, Ugboawka, Enugu State \\ Nigeria-e-mail:obasijen@yahoo.com; phone number: 08052169442 \\ ${ }^{2}$ Department of Economics, Renaissance University, Ugbawka, PMB 01183, Enugu, Enugu State, Nigeria \\ ${ }^{3}$ Adamawa State Polytechnic, Adamawa State
}

\section{*Corresponding Author: -}

Email: obasijen@yahoo.com

\begin{abstract}
: -
This paper is a search light beamed to the investigation of the existing level of domestic resource mobilization, financial access and inclusion for inclusive growth in Nigeria, progressive policy development of government and implementation. Cohesive management of domestic resource mobilization, financial access and inclusion for inclusive growth are the driving force of all vibrant economy of the developed societies of the world, and a panacea to high level productivity of developing nations. Domestic resource mobilization, financial access and inclusion for inclusive growth are elements of political economy; it deals with both micro and macro-economics, with macroeconomics as the branch of economics concerned with the aggregate, or overall, economy. Macroeconomics deals with economics factors such as total national output and income, unemployment, balance of payments, and the rate of inflation, and is distinct from microeconomics, which is the study of the competition of the output such as the supply and demand for individual goals and services, the way they are traded in markets, and the pattern of their relative prices. At the basis of macroeconomics is an understanding of what constitutes national output, or national income, and the related concept of gross national product (GNP), with the GNP being the total value of goods and services provided in an economy during a given period of time, usually a year. This study is aimed at accessing the potentials available to Nigeria through efficient and effective mobilization of domestic resources, access to finance, and inclusion for inclusive growth. Objective of the study is to determine what needs to be done to thoroughly harness domestic resource-mobilization, financial access and inclusion for inclusive growth to galvanize the Nigerian economy. The research question is on the determination of whether domestic resource mobilization, financial access and inclusion help to galvanize inclusive growth. Methodology to be used is primary and secondary data concerning comparative development through domestic resource mobilization, financial access and inclusion for inclusive growth. Results of the finding in the research reveals that there are talents, skills, knowledge and creative skill-banks in Nigeria that are not harnessed because there is not enough support by governments to progressive policies to galvanize the advance lens of the talents, skills, knowledge and creative banks that exist in various corners where there are lots of human resource waste bins). Proffered as solution, is the need for Nigerian government to invest properly and effectively on development strata without discrimination or sentiments.
\end{abstract}

Keywords: - Domestic Resources, Mobilization, Financial Access, Inclusion for Inclusive Growth, Cohesive Management for Vibrant Economy, Development.

\section{(a) $(\$)$}


Contribution/Originality:

This study contributes in the existing level of academic research on policies of government that promote human resource development and management for economic growth in Nigeria. This study uses new estimation methodology that is geared towards reducing corruption in workplace and galvanising the technological base level of Nigeria as a developing nation. This study projects new aggregate level of human societal management and the management of natural and applied resources. This study is one of very few studies which have investigated the result of assessment of nexus concerning measure analysis in human resource development and corruption in relation to logistics management of projects for technological advancement and economic development.

\section{INTRODUCTION}

Growth is good, and sustained high growth is better while sustained high growth with inclusiveness is best of all. A growing GDP is evidence that a society is getting its collective acts together for progress. As a country's economy grows, the society becomes more compactly interwoven. In business management, the philosophy of human capital as domestic resource and an economic foundation provides, 'that (or is concerned with) each member of an economic society is to be assisted to be capable of skills and proficiency that is required to be a contributor to economic, social and political development of his or her country (state, community or organization)' - Nwele (2011). Nigeria has long been recognized as the largest African nation, due to its estimated population of about 168 million inhabitants (2014 estimates). Nigeria faces several challenges especially with the quality of infrastructure and the inclusiveness of growth. Domestic Resource Mobilization is an economic term which states that economic development is a domestically driven enterprise, and that no amount of foreign assistance or investment can substitute for a coherent, dynamic and domestically driven intermediation, mobilization process and capita accumulation. Inclusive of domestic resources are human capital, financial resources, fiscal revenue and remittances - all form important engine of poverty reduction and growth. The Oxford Dictionary of Business (1996), defined inclusion as 'the action of including somebody/something or of being included, while inclusive is concerned with including something; including much or all.' Financial access in broader perspective means non- discrimination, social inclusion and participation for economic development.

The extent of Nigeria's economic success had not been reflected in official data until the year 2014. In April 2014, the federal government began to release data that show GDP of

\$454billion in 2012 and \$510 billion in 2013(compared with the \$259 billion and \$270 billion that were previously reported), confirming Nigeria's lead over South Africa as the largest economy in the continent - based on 1990 price levels and a 1990 view of the economy's structure, which significantly undercounted GDP - (MGI, 2014).

Recent statistics has shown that whereas the World Bank (2013) ranked Nigeria as one of the fastest growing countries of the world with GDP growth rates of 7.8\%(2010), 7.4\%(2011), 7.5\%(2012) and 7.6\%(2013), the UNDP's Human Development Report (2013), ranked Nigeria among the countries with Low Human Development Index (HDI) of 0.471, placing the country at the 153 rd position out of a total of 186 countries sampled. This clearly shows that the present economic growth is not inclusive enough and needs to be addressed. Inclusive growth means: inclusion of all market indices collaborate like; products, price aggregates, resource harnesser machines, and molding principles. Inclusive growth in the economy can only be achieved when all the weaker sectors of the society, including agriculture and small scale industries, are nurtured and brought on par with other sections of the society in terms of economic development. Financial inclusion is the process of ensuring access to appropriate financial products and services needed by vulnerable groups such as low income groups and weaker sections at an affordable cost in a fair and transparent manner by mainstream institutional players of a society. Banking as the financial institution which benefits the economy for efficient payment mechanism and allocation, and a key driver for inclusive growth is no longer a policy choice but a policy compulsion in today's economic development. Access to finance is the ability of individuals or enterprises to obtain financial services, including credit, deposit, payment, insurance, and other risk management services.

Financial access is said to promote growth for enterprises through the provision of credit to both new and existing businesses. Financial access benefits the economy in general by accelerating economic growth, intensifying competition, as well as boosting demand for labour. The lack of financial access limits the range of services and credits for household and enterprises. Individuals who are poor and small enterprises do rely on their personal wealth or internal resources to invest in their education and businesses, this limits their full potential and leading to the cycle of persistent inequality and diminished growth. Inclusive growth is an economic development strategy. Growth is inclusive when it creates economic opportunities along with ensuring equal access to them.

Inclusive growth needs to be inherently sustainable as distinct from income distribution schemes which can in the short run reduce disparities between the poorest and the rest in a society, which may have arisen on account of policies intended to jumpstart growth. While income distribution schemes can allow people, to benefit from economic growth in the short run, inclusive growth allows people to contribute to and benefit from economic growth.

\section{Review of Related Literature}

According to Nwele (2011), "It is a human resource development philosophy, that, managers and human resource professionals have the important job of organizing people so that they can effectively perform production function, in organizations for efficient management of economic and social resources." There are efforts in the past made, to relate the management of human resources to a firm's business strategy or democracy dividend of government; which include matching managerial style or personnel activities with strategies, forecasting manpower requirements given certain strategic objectives or environmental conditions, and presenting means for integrating human resource to corroborate domestic resource for economic growth. 
Millions of people around the world transit from poverty to wellbeing and to plenty in a number of ways, on a yearly bases by adopting new technology modes of farming, investing in new business opportunities or finding new jobs. Banks and other financial services players largely are expected to mitigate the supply side processes that prevent poor and disadvantaged social groups from gaining access to the financial system.

If we are talking of financial stability, economic stability and inclusive growth with stability, it is important to take note that this is not possible without the achievement of financial inclusion. This study contributes to growing literature on the relevance of financial inclusion for the achievement of inclusive growth through the underscoring of the relevance of inclusion in the context of a developing economy like Nigeria, as a society where a large percentage of the population is deprived of the financial services which are essential to the overall inclusive growth.

The objectives of this paper are:

(i) to ascertain the level of financial inclusion in Nigeria and its attendant challenges.

(ii) to understand how financial inclusion could serve to enhance inclusive growth.

(iii) to identify factors that can influence the growth of financial inclusion in Nigeria. (iv) to proffer necessary solutions that can provide for effective domestic resource mobilization, financial access, and inclusion for inclusive growth in Nigeria.

\section{What is inclusion for inclusive growth in Nigeria?}

Human resources or human capital inclusion means that organization, households, or government have access and can effectively use appropriate human resources for common or strategic benefits. Financial inclusion means that households and businesses have access and can effectively use appropriate financial services. Such services shall be provided responsibly and sustainably in a well regulated environment.

Basically, in the ordinary language of social business, what this means is that, to mobilize the domestic resource of a nation, you have to involve all by including every stakeholder in the nation's economic template. Every stakeholder then include: the human capital in their various skills and base, the inventory of resource base, the analysis of comparative advantage and control panel, the financial support available and management skills administration. How does the subsistent farmers in Miya, Zaki, Turum or Cham villages in Bauchi State, Igbosere in Ondo State, Egu-Ekerigwe in Ebonyi State, or even Nkerefi in Enugu State access the financial support needed for positive increase in food production for Nigeria's GDP growth? These are the questions that need to be answered to address the issue of inclusion for inclusive growth in Nigeria's nation building.

In business or governance, according to Nwele and Uduimoh (2015), "Stakeholders are anyone who has a vested interest in the business's success, including the owner, managers, employees, customers and the business's publics." Open and positive communication must be the hallmark of maintaining good working relationships and this depends on timely responses to both successes and failures within the workplace. This means that managers should be sensitive to employee needs and problems and in turn employees should be sensitive to customer wants and needs. All of this has to be balanced with respect for labour laws and anti-discrimination policies which govern workplace relations in societies.

Financial inclusion is central to economic empowerment in rural communities, as it forms the foundation for the sustainable economic development of the less privileged in society. By engaging in economic activities where goods and services are traded for cash, people become part of economic clusters. The amalgamation of economic clusters has an impact on the growth of local economic systems, resulting in sustained development. Thus, in order for sustained socioeconomic development to occur, people should be encouraged to engage in more economic activities where financial transactions take place. To do this, people often need to have bank accounts at formal financial institutions. Studies however, have shown that there are numerous barriers preventing especially the rural poor from entering the formal financial system. Some of these barriers include the cumbersome paperwork associated with opening banking accounts, mandatory deposits, bank charges, the strict 'Know Your Customer' regulations, and the distance from villages to towns, where most formal financial institutions are normally located. Considering this, many rural people may opt to use informal financial institutions, which are risky and mostly unregulated.

An overview is given of financial inclusion in Africa and of the methods through which the financially excluded 'bank' their money and obtain credit.

This paper looks at selected informal remittance mechanisms used by the rural poor to transfer and receive money. In addition, the concept of financial inclusion is presented in context, looking at financial literacy as the element needed to sustain the economic effects of reducing financial exclusion in Nigeria.

World Bank research sows that an estimated 2 billion working-age adults worldwide, i.e. more than half of the total adult population have no access to the types of formal financial services delivered by regulated financial institutions that wealthier people rely on. Instead they depend on informal mechanisms for saving and protecting themselves against risk. They use mechanisms that are risky and often expensive, like buying livestock as a form of savings, pawning jewelry, and turning to the moneylender for credit.

An increasing body of evidence shows that appropriate financial services can help improve household welfare and spur small enterprise activity. There is also macroeconomic evidence to show that economies with deeper financial intermediation tend to grow faster and reduce income inequality.

The microcredit revolution evidence:

The microcredit revolution showed that poor families in the informal economy are valuable clients, and that it is 
possible to serve them in large numbers sustainably. Private sector growth catalyzed by highly-targeted public subsidies are bases upon which GDP grow substantially. We have also learned that poor households need access to the full range of financial services to generate income, build assets, smooth consumption, and manage risks. Domestic financial resources can be harnessed from private savings, remittances, local investors, volunteerism, etc

\section{II.1 Empirical Review}

The theoretical literature discussed above highlights the positive relationship between human resources management and business operations management. According to Hausmann (2014), "any strategy for inclusive economic growth must empower people by including them in the networks of development programmes of the society in question. In a research by Noblesclass Tutorials in Bauchi in 2009; it is stated, "when talented, ambitious recruits are attracted, the business, through good management, builds a strong human organization. The framework of inclusive growth indicators of 'The African Development Bank's (ADB's) Strategy 2020,' is about economic growth with equality of opportunity for all, i.e. maintaining high, efficient, and sustained growth with social inclusion to ensre equal access to opportunities. According to Wikipedia report 2014, Inclusion is one of the most important words spoken with regards to diversity in political economy management.

According to "Encarta Business" (2009), Guatemala's primary natural resources item include: the rich soil of its highland valleys and coastal plains, petroleum, as well as nickel, lead, zinc, iron, and small quantities of gold, silver, and jade; for both domestic use and export. All of these with finance, human capital and modern technology compact makes up domestic resource.

\section{III.Model, Data Sources, Measurement and Estimation Techniques III.1Model and Data Sources}

The theoretical and empirical literature discussed in this research shows that the nexus between domestic resource management and business operations management is crucial to a country's economic growth. The methodology used advanced the conceptual framework imperative to maintaining social tranquility in all segments of Nigeria, as a developing nation.

\section{III.2Estimation of Techniques}

This paper has based the test of techniques on appropriate domestic resource development and management chain in corporate governance objectives and method. The purpose of this is to know who is a stakeholder in the business of leadership, followership, and governance in Nigeria. According to a research by Noblesclass Tutorials in Bauchi in 2009; "access to finance as the ability of individuals or enterprises to obtain financial services, for production purposes or for other legitimate use is imperative for sustainable development." Financial services including credit, deposit, payment, insurance, and other risk management services. Another research by Mona Crest Network, "a production and marketing firm," has shown that financial access promotes growth for enterprises through the provision of credit to both new and existing businesses - Mona Crest 2014.

Financial access inclusion benefits the economy in general by accelerating economic growth, intensifying competition, as well as boosting demand for comparative labour equation. This equation makes it easy for the incomes of those in the lower end of the income ladder to typically rise which in turn reduces income inequality and poverty.

\section{Results and Discussion}

From the results of the research, it is important to note that, because the factors that determine whether or not an individual or enterprise has access to finance may change over time, it makes sense to group the banked and unbanked into market segments that reflect their current and possible future status as users or non-users of financial services. One such approach to market segmentation is the "access frontier," which can be used for analyzing the development of markets over time. The access frontier defines the maximum proportion of the population that has access to a product or service at a given point in time of a society, and the frontier may shift over time, e.g. as the result of technological and competitive changes in the market. The access frontier approach distinguishes between users and non-users of a product or service, and segments non-users into groups which include: those who are able to use the product or service but choose not to - these are known as voluntary non-users; those who should be able to use the product or service within the next two to five years, based on changes in the features of the product or service, or of the market, respectively; and those beyond the reach of market solutions in the next two to five years. The global financial inclusion agenda recognizes these broader needs. It also recognizes the importance of financial literacy, building consumer financial capabilities, and for consumer protection regimes that take the conditions and constraints of poor families in the informal economy into account. To advance financial inclusion, there is a need for continued product and business model innovation so that more people can access a broader range of products at lower costs. Today, worldwide, policy makers are recognizing that financial exclusion is a risk to political stability that impedes economic advancement.

So, between the better understanding of demand, the innovations in supply, and the recognition of the need for a protective and supportive enabling environment, we have the means to advance financial inclusion to improve the lives of the poor, in Nigeria.

\section{Conclusion and Recommendations}

This paper re-examines the relationship between domestic resource possibilities and economic growth, human resource 
as a set of individuals who make up the workforce of an organization, business sector, or economy and governance mechanisms.

The study noted that one of the basic and fundamental goals of any sovereign state (firm or organization) is growth and survival. Therefore, domestic resource mobilization, human resource appraisal functions, and leadership order is panacea to effective business management or governance for survival, growth and stability.

\section{Recommendations}

It is recommended that: government be more determined to refocus the Nigerian national business towards inclusion for inclusive growth, encourage industries to the explicit use of the development of human resources as the engine for extracting and effectively managing well the domestic resource that is at Nigeria's beck and call for inclusive growth of the economy.

\section{References}

[1].Encarta "Business,” Microsoft(R)Encarta(R)2009 (DVD), Rednond, WA; Microsoft corporation, 2008.

[2].Hausmann, Ricardo (2014) "The Economics of Inclusion," www. Project-syndicate.org publications Mona Crest Network, "a production and marketing firm," report contained in a marketing research work

[3].sales analysis 2014.

[4].Noblesclass institute research work (2009), Montae Publications’ Newsletter, December, 2009, Montae Press, B285 Wunti Street, Bauchi.

[5].Nwele J. O. (2011), "Research Analysis and Human Resource Mgt," An Unpublished Seminar Paper, delivered to the class of $2011 \mathrm{PhD}$ Students, in International University, Bamenda, March

[6].Nwele J.O. and Uduimoh A. A. (2015),'Principles of the Analysis of financial Law,' an extract of a text of Commerce, Banking and Financial Law, $2^{\text {nd }}$ Edition, published by Etche Mix Consultants Services Ltd, StR Avenue, GRA, Bauchi; printed by Foramak Press, 12 Edinbourgh Road, Enugu, Nigeria.

[7].Oxford Dictionary of Business (1996), Oxford University Press, Great Clarendon Street, Oxford 0X2 6DP

[8].www. Wikipedia.org/wiki/inclusive/ World Bank 2013 